\title{
Pengembangan Perumahan Berbasis Syariah dan Permasalahannya di Propinsi Jambi
}

\author{
Supeno ${ }^{1}$, M. Ansori ${ }^{2}$ \\ 1,2Fakultas Hukum Universitas Batanghari Jambi \\ Jalan Slamet Riyadi Broni Jambi \\ Correspondence email: msasyabani@gmail.com
}

\begin{abstract}
Abstrak. Penelitian ini bertujuan untuk mengetahui konsep dan pola yang dikembangkan oleh pengembang perumahan berbasis syariah di Propinsi Jambi serta mendeteksi permasalahan yang dihadapi, penelitian menggunakan tipe penelitian empiris dengan cara mewawancari secara langsung direktur perusahaan pengembang dan bagian pemasaran, dari hasil penelitian dapat diperoleh informasi bahwa konsep yang digunakan oleh para pengembang perumahan berbasis syariah adalah konsep bebas dari transaksi riba dan bebas dari kedzaliman berupa bebas dari denda keterlambatan dan bebas dari penyitaan oleh bank konvensional, pola yang dikembangkan dapat berupa pembelian langsung kepada pengembang atau bank syariah membeli rumah kepada pengembang secara kontan kemudian bank syariah menjualnya kepada konsumen secara kredit. Hamabtan yang dihadapi oleh para pengembang adalah masih rendahnya tingkat pemahaman masyarakat tentang konsep perumahan berbasis syariah dan masih adanya praktik yang menghambat proses perizinan yang dilakukan oleh oknum-oknum tertentu. Perlu adanya peran serta pemerintah daerah untuk ikut mengkampanyekan masyarakat bebas riba serta melakukan pengawasan serta ketat terhadap proses perizinan pengembangan perumahan berbasis syariah dari tindakan oknum yang tidak bertanggung jawab.
\end{abstract}

Kata kunci: Perumahan; konsep syariah

Abstract. This study aims to determine the concepts and patterns developed by sharia-based housing developers in Jambi Province and detect problems faced, the research uses empirical research types by directly interviewing the development company directors and marketing department, the research results can be obtained that the concept used by sharia-based housing developers is the concept of free from usury transactions and free from tyranny in the form of free from late fines and free from confiscation by conventional banks, the developed pattern can be in the form of direct purchases to developers or Islamic banks to buy houses to developers in cash then banks Sharia sells it to consumers on credit. Hamabtan faced by the developers is the low level of public understanding of the concept of sharia-based housing and the existence of practices that hinder the licensing process carried out by certain elements. There is a need for the participation of local governments to participate in campaigning for usury-free communities and to supervise and strictly process the licensing of sharia-based housing development from unscrupulous acts.

Keywords: Housing; sharia concept

\section{PENDAHULUAN}

Memiliki tempat tinggal merupakan hak dasar yang dimiliki oleh setiap warganegara sebagaimana diatur dalam Pasal $28 \mathrm{H}$ Ayat 1 Undang-Undang Dasar 1945 "setiap orang berhak hidup sejahtera lahir dan batin, bertempat tinggal, dan mendapatkan lingkungan hidup yang baik dan sehat serta berhak memperoleh pelayanan kesehatan. ${ }^{1}$ Rumah merupakan kebutuhan dasar bagi manusia, sebagai makhluk yang beradab manusia menempatkan rumah tidak hanya sekedar sebagai tempat tinggal saja akan tetapi rumah menjadi tempat pusat peribadatan keluarga (aspek religi), tempat terjadinya interaksi anggota keluarga (aspek sosiologis), tempat berlangsungnya proses pendidikan anggota keluarga (aspek edukatif), rumah sebagai tempat untuk istirahat dan untuk mendapatkan ketenangan, kenyamanan dan ketenangan (aspek psikologi) dan rumah juga dapat menjadi pusat kegiatan ekonomi keluarga (aspek ekonomis). Dengan begitu pesatnya pertumbuhan masyarakat, maka kesempatan untuk memperoleh rumah juga semakin terbatas, untuk kawasan perkotaan praktis sangat sedikit sekali masyarakat yang memiliki lahan sendiri untuk membuat rumah terutama bagi masyarakat yang berasal dari daerah lain dan masyarakat yang tidak mampu.

\footnotetext{
${ }^{1}$ Pasal 28H Ayat 1 Undang-Undang Dasar 1945.
}

Propinsi Jambi memiliki total luas $53435,72 \mathrm{~km} 2$, luas daratan $53010,22 \mathrm{~km} 2$, jumlah kabupaten 9 , kota 2 kecamatan 128 dan kelurahan 1.132. ${ }^{2}$ Berdasarkan data dari Badan Pusat Statistik Propinsi Jambi tahun 2017, pada tahun 2017 jumlah penduduk Propinsi Jambi adalah 3.515.017 jiwa $^{3}$, berdasarkan data kependudukan dari Badan Koordinasi Keluarga Berencana (BKKBN) Propinsi Jambi jumlah penduduk Propinsi yang beragam Islam adalah sebanyak 3.000.000 jiwa ${ }^{4}$ Menurut data dari Badan Pusat Statistik (BPS) Kota Jambi jumlah penduduk miskin di Kota Jambi tahun 2016 berjumlah 51.61 ribu angka ini lebih kecil dibandingkan tahun 2015 sejumlah 55.51 ribu. Hampir $80 \%$ penduduk Propinsi Jambi adalah pendatang, tingginya angka imigrasi ini turut mempengaruhi laju pertumbuhan penduduk di Jambi yaitu 2,55 \% atau diatas rata-rata nasional 1,49\% berdasarkan Sensus Penduduk Tahun 2010.5 Dari beberapa kota/kabupaten dalam Propinsi Jambi, Kota Jambi merupakan sasaran utama para pendatang dengan berbagai macam motif terutama mencari pekerjaan, melanjutkan pendidikan, ikut keluarga dan

2 http://id.m.wikipedia.org, diakses tanggal 28 Desember 2018.

3 Jambikota.go.id, diakses tanggal 21 Februari 2018.

${ }^{4}$ www.kependudukanjambi.org, diakses tanggal 28 Desember

2018.

${ }^{5}$ Suara Pembaharuan, diakses tanggal 22 Februari 2018. 
sebagainya, tercatat hingga Juni 2014 ada 2.737 pendatang baru di Kota Jambi dan data per Juni 2015 sudah mencapai 3.411 jiwa sehingga ada peningkatan jumlah pendatang sebanyak 674 jiwa. ${ }^{6}$ Pertumbuhan ekonomi Propinsi Jambi secara kumulatif pada semester I-2018 mencapai 4,66 persen lebih cepat dibandingkan semester I-2017 yang mencapai 4,62 persen. ${ }^{7}$

Melihat data dan angka di atas dapat diprediksi akan adanya peningkatan masyarakat yang membutuhkan hunian berupa rumah, fenomena dalam suatu kota untuk tempat hunian yang memungkinkan adalah dalam kawasan perumahan, dengan alasan karena keterbatasan lahan, terjangkau oleh kondisi ekonomi masyarakat, akses lebih dekat dengan pusat kota dan perbelanjaan, Badan Pusat Statistik Provinsi Jambi mencatat sektor pembangunan property mengalami pertumbuhan tertinggi di Provinsi Jambi, hal ini disebabkan tingginya permintaan konsumen atas perumahan sederhana maupun perumahan mewah sebagaimana dilansir oleh Tribunnews tanggal 6 Nopember 2012, sebagai contoh pada tahun 2008 rumah yang sudah dibangun oleh masyarakat, perumnas ataupun oleh pengembang di Kota Jambi berjumlah 72.348 unit rumah, ${ }^{8}$ diprediksi angka ini akan semakin meningkat pada masa yang akan datang karena tingginya tingkat pertumbuhan penduduk berupa pembentukan keluarga baru dan pendatang baru di Kota Jambi. Propinsi Jambi mulai menjadi incaran para pengembang untuk membangun perumahan berkelas dari developer local maupun developer sekelas Ciputra, sebagai bukti telah dibukanya areal perumahan Citra Raya City yang memiliki lahan seluas 1.000 hektar.

Penelitian tentang Bank Syariah dalam skala nasional sudah dirintis oleh beberapa peneliti, dalam konteks penelitian ini lebih menekankan kepada Kredit Kepemilikan Rumah (KPR) sederhana yang merupakan kebutuhan utama masyarakat yang memiliki kemampuan ekonomi terbatas, hal ini merupakan pangsa pasar yang memiliki multi-fungsi, pertama menjalankan fungsi sosial yaitu dapat membantu kepemilikan rumah bagi masyarakat yang memiliki keterbatasan secara ekonomi, kedua menjalankan fungsi ekonomi yaitu dapat meningkatkan input-finance bagi bank syariah itu sendiri. Selain itu hal ini memiliki multi-efek, pertama dapat meningkatkan kepercayaan yang besar masyarakat terhadap bank syariah, kedua mampu meningkatkan daya saing perbankan syariah dalam pelayanan pemiliki rumah sederhana, ketiga dapat membantu program pemerintah terutama bagi Kementerian Pemukiman dan Perumahan dalam upaya penyediaan rumah bagi warganegara secara menyeluruh.

Eksistensi bank syariah untuk memerankan peranan di bidang pengadaan rumah sederhana dan masih kalah dengan bank-bank konvensional, sebenarnya bank syariah memiliki kesempatan yang lebih besar dibandingkan dengan bank konvensional karena tingkat kesadaran masyarakat untuk menggunakan bank syariah sebagai mitra semakin

${ }^{6}$ www.jambiupdate.com, diakses tanggal 22 Februari 2018.

7 http://jambi.bps.go.id, diakses tanggal 28 Desember 2018.

${ }^{8}$ Arif Rahman, Pertumbuhan Perumahan di Kota Jambi, Tesis, besar, akan tetapi menuurut Edwin Dwidjajanto Direktur Consumer Banking and Distribution BSM mencatat bahwa selama periode Januari sampai Agustus 2015 pencairan pembiayaan hunian BSM mencapai 1,85 Triliun, sedangkan menurut Kukuh Raharjo Kepala Divisi Konsumer BNI Syariah, BNI Syariah telah menorehkan kinerja bagus di pembiayaan perumahan, posisi outstanding pembiayaan perumahan telah mencapai 7,6 Triliun, angka ini tumbuh $15 \%$ dibandingkan periode yang sama tahun lalu. ${ }^{9}$ Walaupun demikian pertumbuhan trandaksi KPR perumahan berbasis syariah masih kalah dibandingkan transaksi KPR konvensional, beberapa permasalahannya adalah pemahaman masyarakat terhadap produk KPR berbasis syariah masih rendah, konsumen kurang teliti memilih developer. ${ }^{10}$ Sedangkan menurut Heliantopo Direktur PT Sarana Multi Finansial (Persero) bahwa penyaluran KPR konvensional per 31 Juli 2017 sebesar Rp.370,29 triliun, sedangkan penyaluran melalui KPR Syariah hanya Rp.56,16 triliun, sangat kontras dengan jumlah penduduk muslim Indonesia yang mencapai $90 \%$, hal ini disebabkan oleh faktor harga, menurut Ardiansyah Rakhmadi Ketua Pengembangan Produk Syariah Asosiasi Bank Syariah Indonesia (ASBISINDO) menilai pembiayaan rumah yang ditawarkan oleh bank syariah lebih tinggi dibandingkan yang ditawarkan bank konvensional. ${ }^{11}$

Berdasarkan Visi Roadmap Pengembangan Keuangan Syariah Indonesia 2017-2019 yaitu untuk mewujudkan industri jasa keuangan syariah yang tumbuh dan berkelanjutan, berkeadilan, serta memberikan kontribusi bagi perekonomian nasional dan stabilitas sistem keuangan menuju terwujudnya Indonesia sebagai pusat keuangan syariah dunia, untuk mencapai visi tersebut maka visi yang akan dilakukan dalam periode 2017-2019 adalah:

1. Meningkatkan kapasitas kelembagaan dan ketersediaan produk industri keuangan syariah yang lebih kompetitif dan efisien;

2. Memperluas akses terhadap produk dan layanan keuangan syariah untuk memenuhi kebutuhan masyarakat; dan

3. Meningkatkan inklusi produk keuangan syariah dan koordinasi dengan pemangku kepentingan untuk memperbesar pangsa pasar keuangan syariah.

$\mathrm{Di}$ Propinsi Jambi juga mulai tumbuh pengembangan perumahan yang berbasis syariah nonbank yang menawarkan transaksi jual beli perumahan secara langsung dengan developer, pertumbuhan perumahan secara langsung atau non-bank ini juga masih menghadapi berbagai macam kendala dan permasalahan walaupun potensi dan prospek pengembangan perumahan berbasis syariah ini sangat besar karena penduduk Propinsi Jambi mayoritas beragama Islam yaitu sebesar $96,5 \%$ sebagaimana dilansir oleh Wikipedia.

Alhamdulillah saat ini di Propinsi Jambi telah berdiri perusahaan pengembang perumahan yang berbasis syariah, yang perlu didukung agar tetap eksis dan berkembang sebagai bentuk solusi yang sangat
${ }_{9}^{9}$ Tribun.com, diakses tanggal 28 Desember 2018
${ }^{10}$ Economy.okezone.com, diakses tanggal 28 Desember 2018.
${ }^{11}$ Dream.com, diakses tanggal 28 Desember 2018. 
baik bagi masyarakat yang beragama Islam untuk memperoleh rumah bebas dari praktik riba dan sejenisnya, walaupun demikian dalam melaksanakan usahanya masih ditemukan berbagai macam kendala dan permasalahan yang perlu segera diselesaikan, Berdasarkan data dan fakta yang telah diungkapkan di atas, maka dapat disusun rumusan masalah sebagai berikut:

1. Bagaimana konsep dan pola pengembangan perumahan berbasis syariah di Propinsi Jambi?

2. Permasalahan apa saja yang dihadapi oleh para pengembang perumahan berbasis syariah di propinsi Jambi?

\section{METODE PENELITIAN Tipe Penelitian}

Sebagai konsekuensi pemilihan topik yang akan dikaji dalam penelitian yang objeknya adalah permasalahan tentang pengembangan perumahan berbasis syariah di Propinsi Jambi, maka tipe penelitian yang digunakan adalah penelitian empiris, yakni penelitian yang difokuskan untuk mengkaji secara langsung kepada objek penelitian yaitu para pihak pengembang perumahan yang berbasis syariah.

\section{Sumber data}

Dalam melakukan penelitian ini sumber data yang dipergunakan adalah terdiri atas 2 (dua) sumber data yaitu:

\section{a. Penelitian lapangan (field research)}

Yaitu dengan cara melakukan penelitian langsung ke objek penelitian yaitu para pengembang perumahan yang telah menerapkan system syariah, dengan demikian akan diperoleh informasi yang akurat dan objektif berbagai macam kendala dan permasalahan yang dihadapi oleh para pengembang dalam menjalankan bisnisnya.

b. Penelitian kepustakaan (library research)

Penelitian kepustkaan dimaksudkan agar penelitian lapangan yang telah dilakukan dapat diperkuat oleh arguen-argumen hukum dan teori oleh para ahli yaitu dengan cara menelaah peraturan perundangundangan maupun berbagai macam sumber buku yang memiliki keterkaitan dengan penelitian yang dilakukan.

\section{Teknik penarikan sampel}

Dalam penelitian ini teknik pengumpulan data yang dilakukan adalah secara Purposive sampling yaitu dengan menentukan para pihak pengembang perumahan yang menerapkan syariah diantaranya adalah Direktur Utama PT. Amanah Umat Sukses (AUS) dan bagian pemasaran PT. Amanah Umat Sukses, Direktur PT.Mitra Inspira Madani dan bagian pemasaran PT.Mitra Inspira Madani.

\section{Teknik pengumpulan data}

Teknik pengumpulan data yang dilakukan adalah dengan cara wawancara langsung dengan pemilik perusahaan pengembang perumahan berbasis syariah, dengan mempersiapkan berbagai macam pertanyaan yang ditujuakn untuk memperoleh jawaban- jawaban atas permasalahan yang dihadapi para pengembang dalam melaksanakan pengembangan perumahan berbasis syariah, data yang telah diperoleh akan diseleksi dan ada hubungan dengan permasalahan tersebut diklasifikasi sesuai dengan tingkat relevansinya.

\section{Analisis data}

Data yang diperoleh kemudian dianalisis dan dikaji dan menarik kesimpulan dari semua permasalahan yang dibahas secara induktif, kajian dilakukan sedemikian rupa sehingga menggambarkan permasalahan dan pemecahannya secara jelas dan komprehensif.

\section{HASIL DAN PEMBAHASAN \\ Konsep dan pola pengembangan perumahan berbasis syariah di Propinsi Jambi}

Sebelum membahas tentang konsep dan pola pengembangan perumahan berbasis syariah di Propinsi Jambi, sekilas dibahas tentang konsep perumahan syariah menurut para ahli dan hasil penelitian. Muhammad Arifin Badri dalam bukunya Panduan Praktis Fikih Perniagaan Islam menyatakan bahwa "syariat Islam selalu mengajar kemuliaan dan mengajurkannya kepada seluruh umatnya, bukan hanya mengajarkan dan menganjurkan kemuliaan, Islam juga melarang umatnya dari segala bentuk kehinaan dan segala hal yang dapat mendatangkan kehinaan, $^{12}$ salah satu bentuk kehinaan dalam Islam adalah praktik pemberian bunga (riba) yang diterapkan oleh bank konvensional, yang secara jelas adanya larangan baik dalam Al-Qur'an maupun As-Sunnah."tidak asing lagi bahwa riba adalah salah satu hal yang diharamkam dalam Islam. Sangat banyak dalil yang menunjukkan akan keharaman riba dan berbagai sarana terjadinya riba."13 Menurut Erwandi Tarmizi "tidak seorang muslimpun yang menyangkal haramnya hukum riba. Teks Alqur'an begitu jelas menyatakan bahwa Allah telah mengharamkan riba."14 Diantaranya secara tegas diatur dalam Surah AlBaqarah:278, Surah Al-Baqarah:279.

Edukasi terhadap masyarakat tentang transaksi syariah dewasa ini menunjukan intensitas yang cenderung meningkat, kesadaran masyarakat Muslim Indonesia terhadap transaksi yang dibolehkan dan dilarang semakin mengemuka, kesadaran masyarakat akan haramnya hukum riba semakin baik pula, secara perlahan-lahan masyarakat mulai meninggalkan praktik riba. Efek positifnya adalah semakin banyak masyarakat yang membuka rekening di bank-bank syariah, hal ini merupakan kondisi yang perlu disyukuri bersama dan menjadi peluang dan tugas yang besar bagi pemerintah dan pemegang kepentingan untuk membuka akses yang seluas-luasnya pelayanan bank syariah agar kesadaran dan perwujudannya dapat berjalan secara seimbang.

Bank Islam menurut Veithzal Rivai adalah "bank yang beroperasi dengan tidak mengandalkan pada bunga, bank Islam disebut pula dengan bank tanpa bunga adalah lembaga keuangan/perbankan yang operasional dan produknya dikembangkan berdasarkan

\footnotetext{
${ }^{12}$ Muhammad Arifin Badri, Panduan Praktis Fikih Perniagaan Islam, Darul Haq, Jakarta, 2015, hal.1.

${ }^{13}$ Muhammad Arifin Badri, Riba dan Perbankan Syariah, Pustaka Al-Furqon, Gresik, 2015, hal. 2.

${ }^{14}$ Erwandi Tarmizi, Harta Haram Muammalat Kontemporer, Berkat Mulia Insani, Bogor, 2016, hal. 387.
} 
pada Al-Qur'an dan Hadist. ${ }^{15}$ Sehingga ciri utama dari bank syariah adalah bebas dari praktik-praktik riba yang sangat dilarang dan akan mengakibatkan dosa bagi pelakunya dan secara finansial akan merugikan para nasabah yang meminjam uang di bank-bank konvensional.

Dasar hukum perbankan syariah adalah UndangUndang Nomor 21 Tahun 2008 Tentang Perbankan Syariah, perbankan syariah didirikan bertujuan untuk menunjang pelaksanaan pembangunan nasional dalam rangka meningkatkan keadilan, kebersamaan, dan pemerataan kesejahteraan rakyat (Pasal 3). Bank Syariah mengemban tugas yang mulia yaitu untuk mencapai kesejahteraan rakyat, masyarakat berharap agar bank syariah dapat mengemban tugas tersebut dengan baik dan benar-benar dapat meningkatkan kesejahteraan rakyat termasuk memenuhi kebutuhan dasar manusia yaitu tempat tinggal (rumah).

Rosyida (2013) dalam laporan hesil penelitiannya menyatakan bahwa bagi masyarakat yang memiliki kemampuan dalam keuangan, membeli sebuah rumah secara tunai bukanlah sebuah kendala. Namun bagi masyarakat yang memiliki keterbatasan dalam keuangan, membeli rumah secara tunai menjadi sebuah kendala. Sehingga banyak masyarakat yang memilih membeli rumah secara kredit. Hal ini disebabkan pembayaran secara kredit dianggap lebih ringan dibandingkan pembayaran secara tunai. Banyaknya kebutuhan masyarakat akan kredit rumah membuat bank mengeluarkan produk-produk pembiayaan, seperti Kredit Pemilikan Rumah (KPR).

Produk KPR merupakan produk yang dikeluarkan oleh kalangan perbankan dalam rangka membantu masyarakat memenuhi kebutuhan perumahan mereka. Keikutsertaan kalangan perbankan dalam membantu pengadaan perumahan bagi masyarakat sangat penting karena merupakan bagian dari program pemerintah untuk membantu pengadaan perumahan bagi masyarakat. Sedemikian pentingnya masalah perumahan tersebut membuat pemerintah bersama DPR telah mengeluarkan UU No 4 tahun 1992 yang menegaskan dalam Bab 1 Pasal 1: "rumah adalah bangunan yang berrfungsi sebagai tempat tinggal atau hunian dan sarana pembinaan keluarga."Dalam dunia perbankan, produk ini biasa dinamakan dengan Kredit Pemilikan Rumah atau biasa dikenal dengan nama KPR. Dalam KPR yang biasa dijalankan oleh perbankan konvensional produk tersebut dapat dipastikan tidak akan lepas dari bunga yang merupakan ciri utama dari bank konvensional. Dalam KPR konvensional biasa terlibat berbagai unit-unit lain seperti pihak perseroan terbatas yang akan menyediakan lokasi yang dipergunakan dalam kegiatan pembangunan rumah. Selain itu juga terdapat hal lain yang terdapat dalam KPR konvensional diantaranya adalah harga jual yang bersifat kontan, uang muka dan suku bunga angsuran yang harus dibayarkan oleh nasabah serta berbagai barang dan juga keperluan lain yang harus dibayarkan oleh pihak debitur. KPR sendiri dibagi menjadi dua, yaitu KPR subsidi dan KPR non subsidi. Yang dimaksud dengan KPR subsidi adalah KPR yang diperuntukkan

${ }^{15}$ Veithzal Rivai dan Rifki Ismail, Islamic Risk Management for Islamic Bank, Kompas Gramedia, Jakarta, 2013, hal. 24. untuk masyarakat yang memiliki kemampuan ekonomi yang lemah. Sedangkan yang dimaksudkan dengan KPR non subsidi adalah KPR yang diperuntukkan bagi seluruh masyarakat tanpa adanya campur tangan dari pihak pemerintah.

Konsep Kredit Pemilikan Rumah (KPR) yang ada pada perbankan syariah pada dasarnya berbeda dengan Konsep Kredit Pemilikan Rumah (KPR) yang ada di perbankan konvensional. Perbedaan ini dapat terjadi karena terdapat perbedaan prinsip antara perbankan syariah dengan perbankan konvensional. Dalam perbankan syariah biasa dikenal konsep berbasis bagi hasil dan juga perdagangan. Sedangkan dalam perbankan konvensional dikenal sistem yang berbasis bunga. Dalam produk yang biasa dikenal dengan nama Kredit Pemilikan Rumah (KPR) syariah ini terdapat beberapa karakteristik yang berbeda, di antaranya adalah tidak adanya pemberlakuan sistem kredit yang ada pada perbankan konvensional. Sementara pada perbankan syariah dikenal sistem murabahah yang berbasis margin, musyarakah mutanaqisah yang memiliki ciri khas partisipasi kepemilikan.

Kredit Pemilikan Rumah (KPR) syariah dapat juga menggunakan akad murabahah yang berbasis jual beli. Dalam kebiasaan yang ada pada perbankan syariah konsep murabahah merupakan konsep perdagangan berbasis jual beli yang pembayarannnya dilakukan secara tangguh atau cicilan. Dalam akad ini pihak bank syariah bertindak sebagai penjual yang akan melakukan penjualan aset kepada nasabahnya secara tangguh atau dengan cicilan. Dalam akad murabahah pihak bank syariah akan melakukan penjualan barang dagangan kepada para nasabahnya dengan keuntungan yang telah disepakati oleh kedua belah pihak. Akad KPR syariah yang menggunakan sistem murabahah membuat pihak bank syariah harusmemberitahukan kepada pihak nasabahnya berkaitan dengan harga perolehan rumah yang diperoleh bank syariah dari pihak developer. Kemudian bank syariah dengan harga tersebut lalu menetapkan keuntungan yang akan diambilnya di mana margin keuntungan tersebut disepakati oleh kedua belah pihak.

PT. Mitra Inspira Madanai (MMI) adalah salah satu perusahaan pengembang perumahan yang ada di Propinsi Jambi, perusahaan yang digawangi oleh Muchdian, ST ini telah membangun perumahan dengan konsep syariah di Jalan Bluru Desar Mekar Jaya Kabupaten Muaro Jambi dan di beberapa tempat di wilayah Kota Jambi, sudah ada rencana untuk membangun perumahan di Desa Sungai Duren, sampai saat ini PT. Mitra Inspira Madanai (MMI) telah membangun dan memasarkan sebanyak 67 unit rumah. $^{16}$ Konsep syariah yang dikembangkan oleh perusahaan sebagaimana konsep transaksi syariah menurut Islam yaitu transaksi jual beli tidak mengandung riba, rumah sudah dibangun terlebih dahulu kemudian baru dipasarkan, tidak ada denda keterlambatan, jika konsumen tidak mampu untuk melanjutkan kreditnya maka perusahaan memfasilitasi konsumen untuk dijual kepada pihak lain, hasil penjualan akan dilunasi sisa kredit dan sisianya menjadi milik konsumen.

16 Hasil Wawancara dengan Muchdian, ST pada tanggal 14 Agustus 2019. 
Jika disimak dengan teliti konsep pengembangan perumahan berbasis syariah oleh PT. Mitra Inspira Madanai (MMI) sangat membantu masyarakat yang belum memiliki rumah terutama bagi masyarakat yang tidak mampu, betapa tidak praktik ini akan menghindari kedua belah pihak pihak terlibat dalam parktik riba sehingga terhindar dari perbuatan dosa, akibat dari transaksi riba yang dikembangkan oleh transaksi ribawi dengan adanya pertambahan dan denda keterlembatan dimana konsumen tidak mampu lagi untuk membayar tidak sedikit dari masyarakat yang harus kehilangan uang yang sudah disetor dan kehilangan rumah yang sudah dibeli, karena itu sudah menjadi pemandangan yang biasa hampir di setiap perumahan yang menggunakan konsep ribawi ada rumah yang disita oleh bank.

Dalam konsep syariah jika terjadi sengketa maka akan diupayakan dulu melalui jalur musyawarah, jika tidak dapat diselesaikan secara musyawarah maka dapat diselesaikan melalui jalur hukum sebagaimana yang tertuang di dalam surat perjanjian yang ditandatangani oleh kedua belah pihak, menurut Muchdian, ST sampai saat ini tidak ada sengketa yang terjadi antara kedua belah pihak. ${ }^{17}$ Diakui bahwa konsep perumahan berbasis syariah merupakan model transaksi yang jauh dari timbulnya perselisihan karena kedua belah pihak memiliki itikad baik dan saling menguntungkan dan tidak ada praktik kedzaiman di antara kedua belah pihak.

Tentang pola yang dikembangkan oleh para pengembang perumahan berbasis syariah di Propinsi Jambi dalam memasarkan produk perumahan syariah perlu disimak penuturan Irfandi Mardi Putra $^{18}$ dalam penelitiannya menyatakan bahwa barang yang diperjualbelikan, harga dan keuntungan telah disepakati oleh kedua belah pihak dengan mekanisme pemilik barang bertransaksi dengan calon nasabah yang bertindak selaku kuasa bank dengan membeli barang tersebut. Selanjutnya setelah secara prinsip kepemilikan berpindah pada bank, bank (penjual II) akan menjual barang tersebut pada nasabah.

Dalam transaksi perumahan berbasis syariah, ada beberapa pola yang dikembangkan oleh PT. Mitra Inspira Madanai (MMI) yaitu:

a. Pembelian secara langsung antara pengembang dengan konsumen yang dapat dilakukan secara kontan maupun secara kredit;

b. Pembelian melalui bank syariah, di mana pengembang menjual perumahan kepada bank syariah selanjutnya bank syariah menjual kepada konsumen yang dapat dilakukan secara kontan maupun secara kredit

Perumahan berbasis syariah yang dibangun oleh PT. Amanah Umat Sukses (AUS) Kredit Syar'i juga mengemban misi untuk memperkenalkan konsep perumahan syariah terutama untuk menghilangkan praktik riba, dan kedzaliman berupa denda dan sita. PT. Amanah Umat Sukses (AUS) hadir untuk memberikan

\footnotetext{
17 Hasil Wawancara dengan Muchdian, ST pada tanggal 14 Agustus 2019.

18 Irfandi Mardi Putra, Strategi pembiayaan kepemilikan rumah Bank Syariah Studi Kasus PT. BNI Syariah Surabaya Dharmawangsa, Jurnal Ilmu dan Riset manajemen Volume 3 Nomor 12 Tahun 2014.
}

solusi bagi masyarakat yang ingin memiliki rumah yang terbebas dari riba, pada saat ini PT. Amanah Umat Sukses (AUS) sudah menyediakan 24 (dua puluh empat) kavling tanah perumahan siap bangun di Desa Mendalo Darat Kabupaten Muaro Jambi. ${ }^{19}$

Konsep pengembangan yang dilakukan oleh PT. Amanah Umat Sukses (AUS) Kredit Syar'i konsumen membeli secara langsung kepada pengembang dengan pola kontan dan kredit, ada dua bentuk transaksi yaitu pertama dapat membeli tanah kavlingnya saja atau kedua dibangunkan rumah oleh pengembang, untuk bentuk yang pertama jika akan membangun rumah sendiri bagian depan rumah harus seragam dengan konsep rumah yang dibangun oleh pengembang. ${ }^{20}$

Terlihat bahwa konsep pengembangan perumahan berbasis syariah ini adalah pertama untuk menghidupkan konsep transaksi yang dihalalkan oleh Allah yaitu bebas dari transaksi riba, bebas dari kedzaliman yaitu bebas dari denda dan bebas dari penyitaan oleh bank, kedua memberikan solusi kepada masyarakat yang ingin memiliki rumah secara kredit dengan harga terjangkau dimana selama ini masyarakat hanya tahu bahwa untuk memiliki rumah harus berhubungan dengan bank konvensional, yang selama ini masyarakat banyak yang menjadi korban pada saat mereka tidak mampu lagi untuk menyicil rumah mereka sehingga banyak diantara rumah mereka disita oleh bank.

\section{Permasalahan yang dihadapi oleh para pengembang perumahan berbasis syariah di propinsi Jambi}

Bahwa dari 11 bank umum syariah yang ada di Indonesia 6 di antaranya memiliki pembiayaan untuk KPR syariah meskipun dengan jumlah yang fluktuatif. Berfluktuasinya KPR syariah yang dikeluarkan oleh perbankan syariah lebih banyak disebabkan pemahaman masyarakat yang belum benar tentang konsep KPR syariah tersebut. Penelitian awal yang dilakukan di PT Bank Muamalat menunjukkan hasil bahwa perlu adanya pengembangan yang dilakukan agar produk KPR syariah dapat lebih mudah dipahami oleh para calon nasabah. Sementara dari data yang diperoleh mengenai perkembangan KPR syariah yang dmiliki oleh PT BTN syariah, dapat dilihat bahwa naik turunnya jumlah KPR syariah yang dapat direalisasikan menunjukkan bahwa KPR syariah di bank tersebut belum dapat dijadikan sebagai produk unggulan dari bank itu. Penelitian lanjutan perlu dilakukan dengan data yang lebih banyak, sehingga simpulan mengenai tingkat pemahaman KPR syariah ini bisa diperoleh secara lebih komprehensif. Penelitian tentang Bank Syariah dalam skala nasional sudah dirintis oleh beberapa peneliti, dalam konteks penelitian ini lebih menekankan kepada Kredit Kepemilikan Rumah (KPR) sederhana yang merupakan kebutuhan utama masyarakat yang memiliki kemampuan ekonomi terbatas, hal ini merupakan pangsa pasar yang memiliki multi-fungsi, pertama menjalankan fungsi sosial yaitu dapat membantu
19 Hasil wawancara dengan Ahmad Rupandi selaku bagian pemasaran PT. Amanah Umat Sukses (AUS) pada tanggal 14 Agustus 2019.

${ }^{20}$ Wawancara by phone dengan Hasbi Munawar, S.T selaku Direktur PT. Amanah Umat Sukses (AUS) Kredit Syar'i. 
kepemilikan rumah bagi masyarakat yang memiliki keterbatasan secara ekonomi, kedua menjalankan fungsi ekonomi yaitu dapat meningkatkan input-finance bagi bank syariah itu sendiri. Selain itu hal ini memiliki multi-efek, pertama dapat meningkatkan kepercayaan yang besar masyarakat terhadap bank syariah, kedua mampu meningkatkan daya saing perbankan syariah dalam pelayanan pemiliki rumah sederhana, ketiga dapat membantu program pemerintah terutama bagi Kementerian Pemukiman dan Perumahan dalam upaya penyediaan rumah bagi warganegara secara menyeluruh. ${ }^{21}$

Ketidakjelasan informasi tentang bank syariah, jaringan kantor yang terbatas, dan tidak tahu tentang produk bank syariah merupakan alasan utama kenapa mereka belum berhubungan dengan bank syariah. Menunjukkan masih banyaknya pekerjaan rumah Bank Indonesia (BI) untuk lebih memasyarakatkan bank syariah karena kurangnya informasi dari pemangku kepentingan mengakibatkan persepsi masyarakat terhadap bank syariah masih simpang siur, akses yang sangat terbatas dari bank syariah yang sulit terjangkau oleh masyarakat, bahkan hasil pantauan penulis di Propinsi Jambi masih ada di ibukota kabupaten tidak ada bank syariah hal ini merupakan ironi yang menyedihkan, dengan keterbatasan tersebut mengakibatkan masyarakat tidak mengetahui produkproduk yang ada di bank syariah. ${ }^{22}$

Dari beberapa hasil penelitian di atas menunjukkan bahwa kesadaran masyarakat Indonesia yang merupakan mayoritas beragama Islam untuk meninggalkan praktik riba di bank-bank konvensional masih rendah, karena berbagai faktor sebagaimana yang telah diutarakan di atas, masih ditemukan berbagai macam permasalahan seperti kurangnya akses bank syariah di tengah-tengah masyarakat sehingga pengetahuan masyarakat tentang bank syariah dan produk-produknya masih minim, sehingga masyarakat "terpaksa" masih berhubungan dengan bank konvensional termasuk dalam upaya untuk memperoleh rumah sederhana, padahal objek garapan yang satu ini merupakan objek garapan yang sangat menjanjikan dengan asumsi masyarakat dapat dipastikan ingin memiliki rumah.

Secara umum di Jambi dibandingkan antara masyarakat yang menyadari tentang larangan bertransaksi riba dengan masyarakat yang sudah memahaminya masih timpang jumlahnya, yaitu lebih dominan yang belum memahami bahaya riba, oleh karena itu jika perumahan yang ditawarkan kepada masyarakat umum mereka lebih percaya dengan rumah subsidi yang disediakan oleh pemerintah. Oleh karena itu konsumen yang membeli perumahan yang dibangun Mitra Inspirasi Madani adalah mereka yang sudah mengenal dan memahami konsep syariah. ${ }^{23}$

${ }^{21}$ Muhammad Heykal, Analisis Tingkat Pemahaman KPR Syariah pada Bank Syariah di Indonesia: Studi Pendahuluan, Binus Bussines Review Vol. 5 Nomor 2 November 2014

${ }^{22}$ Harif Amali Rivai, et. al. Identifikasi faktor penentu keputusan konsumen dalam memilih jasa perbankan: Bank Syariah vs Bank Konvensional, Kerjasama Bank Indonesia dan Center for Banking Research Universitas Andalas.

${ }^{23}$ Hasil Wawancara dengan Sugiantoro, Staf Pemasaran PT. Mitra Inspira Madani, pada tanggal 14 Agustus 2019.
Permasalahan lain yang dihadapi oleh PT. Mitra Inspira Madani dalam mengembangkan perumahan berbasis syariah adalah pada saat mengurus berbagai macam perizinan, yaitu masih ada praktik menghambat perizinan yang dilakukan oleh oknum-oknum tertentu, akan tetapi PT. Mitra Inspira Madani tetapi melaksanakan prosedur yang ditetapkan dan tidak melayani berbagai macam upaya untuk melakukan rasuah walaupun akibatnya surat izin relatif lebih lama. ${ }^{24}$

Sejauh ini secara umum permasalahan yang dihadapi PT. Amanah Umat Sukses (AUS) Kredit Syar'i adalah tingkat pemahaman masyarakat masih cenderung memilih perumahan dengan konsep konvensional, belum begitu memahami konsep perumahan syariah, oleh karena itu mayoritas konsumen yang membeli tanah kavling dan perumahan PT. Amanah Umat Sukses (AUS) Kredit Syar'i adalah masyarakat dalam komunitas terbatas yang telah memahami konsep perumahan syariah. ${ }^{25}$ Dalam masalah pengurusan perizinan PT. Amanah Umat Sukses (AUS) Kredit Syar'i belum menemukan hambatan dan permasalahan yang berarti karena pada saat ini baru hanya terbatas pada pembelian objek perumahan dan belum pada tahap pembangunan perumahan.

Dengan demikian secara umum kendala yang dihadapi oleh para pengembang dalam mengembangkan perumahan berbasis syariah ini tingkat pengetahuan dan kesadaran masyarakat terhadap konsep syariah masih rendah hal ini bisa dilihat masih minimnya minat masyarakat umum yang membeli perumahan berbasis syariah, dan pada umumnya yang membeli rumah adalah mereka yang telah memiliki ilmu syar'i sehingga hanya dalam komunitas yang terbatas. Sedangkan permasalahan yang dihadapi adalah masih adanya upaya yang dilakukan oleh oknum oknum tertentu yang menghambat dalam proses perizinan dengan berbagai macam trik sehingga menghambat terbitnya berbagai macam perizinan yang harus dimiliki pengembang.

\section{SIMPULAN}

1. Bahwa konsep yang dikembangkan oleh para pengembang perumahan berbasis syariah adalah konsep perumahan bebas dari riba dan kedzaliman berupa bebas denda dan bebas penyitaan dari bank konvensional, konsep ini sesuai dengan tuntunan ajaran Islam, pola yang dikembangkan berupa pembelian secara langsung dengan pengembang atau pihak bank syariah membeli unit perumahan secara kontan kepada pengembang dan pihak bank syariah menjualnya kepada konsumen secara kredit.

2. Hambatan yang dihadapi oleh para pengembang adalah masih rendahnya pemahaman masyarakat tentang konsep perumahan berbasis syariah sehingga konsumen yang membeli masih terbatas dari komunitas yang sudah memahami dengan baik konsep perumahan berbasis syariah sesuai dengan

${ }^{24}$ Hasil Wawancara dengan Muchdian, ST pada tanggal 14 Agustus 2019

${ }^{25}$ Hasil Wawancara dengan Ahmad Rupandi, Staf Pemasaran PT.Amanah Umat Sukses (AUS) Kredit Syar'i, pada tanggal 14 Agustus 2019. 
ajaran Islam, permasalahan yang dihadapi oleh para pengembang adalah masih ada oknum-oknum tertentu yang menghambat proses perizinan perumahan berbasis syariah

\section{Rekomendasi}

1. Diharapkan kepada Pemerintah Propinsi Jambi dan Pemeintah Kota dan Kabaupaten untuk dapat membantu mengkampanyekan kepada masyarakat tentang bahaya riba dengan menggunakan mediamedia yang dimiliki oleh pemerintah agar kesadaran masyarakat Propinsi Jambi tentang bahaya riba akan semakin baik sehingga kesejahteraan masyarakat akan semakin meningkat dan diperoleh sesuai dengan ajaran Islam.

2. Diharapkan kepada Pemerintah Propinsi Jambi maupun Pemerintah Kota dan Kabupaten untuk melakukan pengawasan yang lebih ketat terhadap tindakan oknum-oknum tertentu yang menghambat pengurusan izin perumahan berbasis syariah di Propinsi Jambi.

\section{DAFTAR PUSTAKA}

\section{Buku-buku}

A. Wangsawidjaja Z, Pembiayaan Bank Syariah, Gramedia Pustaka Utama, Jakarta, 2012.

Erwandi Tarmizi, Harta Haram Muammalat Kontemporer, Berkat Mulia Insani, Bogor, 2016

Muhammad Arifin Badri, Panduan Praktis Fikih Perniagaan Islam, Darul Haq, Jakarta, 2015

Riba dan Perbankan Syariah, Pustaka Al-Furqon, Gresik, 2015

Viethal Rivai, Islamic Risk Management for Islamic Bank, Gramedia Pustaka Utama, Jakarta, 2013.

Zainuddin Ali, Hukum Islam: Pengantar IImu Hukum Islam di Indonesia, Sinar Grafika, Jakarta, 2015.

\section{Jurnal IImiah}

Harif Amali Rivai, et. al. Identifikasi faktor penentu keputusan konsumen dalam memilih jasa perbankan: Bank Syariah vs Bank Konvensional, Kerjasama Bank Indonesia dan Center for Banking Research Universitas

Irfandi Mardi Putra, Strategi pembiayaan kepemilikan rumah Bank Syariah Studi Kasus PT. BNI Syariah Surabaya Dharmawangsa, Jurnal IImu dan Riset manajemen Volume 3 Nomor 12 Tahun 2014.

Muhammad Heykal, Analisis Tingkat Pemahaman KPR Syariah pada Bank Syariah di Indonesia: Studi Pendahuluan, Binus Bussines Review Vol. 5 Nomor 2 November 2014. 